\title{
Proximate analysis and mineral constituents of Macrolepiota dolichaula and soils beneath its fruiting bodies
}

\author{
Rizal $\mathrm{LM}^{1,2}$, Hyde KD ${ }^{1,2}$, Chukeatirote $\mathrm{E}^{1,2}$ and Chamyuang $\mathrm{S}^{1,2}$ \\ ${ }^{1}$ School of Science, Mae Fah Luang University, Chiang Rai 57100, Thailand \\ ${ }^{2}$ Centre of Excellence in Fungal Research Mae Fah Luang University, Chiang Rai 57100, Thailand
}

Rizal LM, Hyde KD, Chukeatirote E, Chamyuang S 2015 - Proximate analysis and mineral constituents of Macrolepiota dolichaula and soils beneath its fruiting bodies. Mycosphere 6(4), 414-420, Doi 10.5943/mycosphere/6/4/3

\begin{abstract}
The nutritional quality of Macrolepiota dolichaula (strain MFLUCC 13-0579) grown in orchard soils was investigated. Proximate analysis showed $M$. dolichaula fruiting bodies to contain $27 \%$ protein, $38 \%$ carbohydrates, $15 \%$ fiber, $2 \%$ lipid, $10 \%$ ash and $8 \%$ moisture. The energy value was calculated as $286 \mathrm{KJ}$ per $100 \mathrm{~g}$ dry weight of mushroom. The content of seven essential minerals in this mushroom, as well as top soils $(0-5 \mathrm{~cm})$ below the mushrooms were explored. In addition, the bioaccumulation potential of minerals in the fruiting bodies were calculated as a ratio between the mineral concentration in the mushrooms and the soil concentration were studied. Mineral contents were $\mathrm{Fe}$ (15.94 in mushrooms; 5.77 in soil), $\mathrm{Na}(5.83 ; 2.78), \mathrm{Cu}(1.94 ; 0.64), \mathrm{Zn}$ $(1.69 ; 0.99)$ and $\mathrm{Mg}(0.99 ; 0.61), \mathrm{Mn}(0.81 ; 2.21)$ and $\mathrm{Ca}(0.34 ; 14.58)$ for $\mathrm{mg} / 100 \mathrm{~g}$ dry weight. The bioconcentration factors (BCF), showed that this mushroom is efficient in the absorption of Fe, $\mathrm{Na}, \mathrm{Zn}$ and $\mathrm{Mg}$ which are low in soils $(\mathrm{BCF}>1)$, while $\mathrm{Ca}$, and $\mathrm{Mn}$ are poorly absorbed in its fruiting bodies, although the $\mathrm{Ca}$ and $\mathrm{Mn}$ contents in soils were high $(\mathrm{BCF}<1)$. Based on this study, it can be concluded that $M$. dolichaula is a good dietary source of essential nutrients and minerals which are found within the acceptable limits for human consumption.
\end{abstract}

Key words - Cultivated mushroom - minerals bioaccumulation - nutritional supplements

\section{Introduction}

Macrolepiota dolichaula is consumed as a seasonal delicacy in China and Thailand (Ge et al. 2010, Kumari \& Atri 2014). It is also used as a remedy for indigestion and to treat anemia by the locals in north west India (Kumari et al. 2012). In tropical regions it usually grows on fertile soils, where there has been a certain degree of disturbance, such as on pastures and roadsides (Ge et al. 2010, Kumari et al. 2012, Kumari et al. 2014).

Macrolepiota dolichaula is readily recognized due to its large, fleshy pileus covered, with squamules forming striking patterns. The taxon is a saprobe, which can grow in various culture media and agricultural wastes, which makes it a potential resource for cultivation. Macrolepiota dolichaula contains significant amounts of vitamins $\mathrm{A}, \mathrm{B}_{1}, \mathrm{~B}_{2}, \mathrm{~B}_{3}, \mathrm{C}$ and $\mathrm{D}$, including thiamine, riboflavin and has laccase activity (Kumari et al. 2012). Two water soluble polysaccharides (PS-I \& PS-II) have also been isolated from its fruiting body extracts (Samanta et al. 2013).

Macrolepiota species are known to bioaccumulate and recycle minerals during plant biomass degradation. Some minerals are efficiently accumulated, whereas others are excluded. 
Accumulated minerals are important as nutrients for animals and humans. This study determined the nutritional contents and essential minerals in fruiting bodies of the mushroom and in soils below the mushroom fruiting bodies. Furthermore, the mineral accumulating capacities in the fruiting bodies of this mushroom were investigated. Analytical data on nutritional and mineral contents are expected to be used as a reference for food composition and nutritional values. The mineral accumulating capacity of this mushroom could be used as a potential bioindicators of mineral contents of soils (Vetter \& Siller 1997, Falandysz et al. 2008b, Falandysz \& Gucia 2008, Baptista et al. 2009).

\section{Materials \& Methods}

\section{Cultivation, samples collection and preparation}

Spawn of M. dolichaula (strain MFLUCC 13-0579) were directly inoculated in the soil in a $15 \times 45 \mathrm{~cm}$ deep pit in orchard soils at the Mushroom Research Farm in Bandu, Chiang Rai. The mycelium was covered with soil and litter. After ten months and during the rainy season, fruiting bodies of all stages were harvested and characterized. Soil samples $(0-5 \mathrm{~cm} ; 15 \mathrm{~g})$ beneath the fruiting bodies were also collected and air dried. The $\mathrm{pH}$ value of the soil samples were measured. Whole sporocarps (pileus and stipe) were dried at $40^{\circ} \mathrm{C}$ for 24 hours and subsequently microcharacters were studied from dry specimens, which were mounted on slides in $5 \% \mathrm{KOH}$ and stained with Congo red. The remaining dried specimens were stored in plastic bags with collection numbers and deposited at Mae Fah Luang University (voucher specimen no. MFLUCC 13-0579) for long term herbarium storage and further study. Dried mushrooms $(60 \mathrm{~g})$ and soils samples were powdered in a mechanical grinder, sieved through a pore size of $2 \mathrm{~mm}$ and stored in air tight plastic bags prior to proximate nutritional analysis and mineral testing.

\section{Proximate nutritional analysis}

The proximate nutritional analysis of fruiting body powder was carried out using the methods from the Association of the Official Analytical Chemist (AOAC 1995). Moisture content was established by drying $2 \mathrm{~g}$ of test sample at $105^{\circ} \mathrm{C}$ for 16 hours in a hot air oven (UM500, Memmret). The ash content was measured by combusting $2 \mathrm{~g}$ of the mushroom fruiting body in an electric furnace (Eurotherm $2416 \mathrm{CG}$, Lento) at $505^{\circ} \mathrm{C}$ for two hours. Fiber content was determined by acid treatment and subsequent heating of $1 \mathrm{~g}$ sample at $500^{\circ} \mathrm{C}$, in the Fibertec system M10020 Extractor (Foss Tecator). The protein content was estimated by the Kjeldahl method in which the protein content was estimated by multiplying by a conversion factor of $\mathrm{N} \times 4.38$ (Fujihara et al. 1995). Lipids were determined by the Soxtec 20055 Extraction unit (Foss Tecator) with petroleum ether. The total carbohydrate and energy value were calculated according to the following equations Carbohydrate $(\%)=100-(\mathrm{g}$ moisture $+\mathrm{g}$ ash $+\mathrm{g}$ lipid $+\mathrm{g}$ protein $+\mathrm{g}$ fiber $)$ (Colak et al. $2007)$. Energy $(\mathrm{kJ})=4 \times(\mathrm{g}$ protein $)+4.2 \times(\mathrm{g}$ carbohydrate $)+9.10 \times(\mathrm{g}$ fat $)$ respectively $($ Kumari $\&$ Atri 2014). All experiments were carried out in triplicate.

\section{Mushroom and soil sample preparation for mineral content analysis}

Powdered mushroom $(2 \mathrm{~g})$ was placed in an electric furnace (Eurotherm 2416CG, Lento) at $550{ }^{\circ} \mathrm{C}$ for four hours until becoming ash. The resulting soil $(2.00 \mathrm{~g})$ and ash were digested with 7.5 $\mathrm{ml}$ concentrated nitric acid (Conc. HNO3; 65\%) in quartz beakers and left for 24 hours. The digest were filtered through filter paper (Whatman No. 1) into polyethylene bottles and further diluted to $50 \mathrm{ml}$ using double deionized water prior to the mineral test.

\section{Mineral content analysis of mushrooms and soils}

$\mathrm{Ca}, \mathrm{Mg}, \mathrm{Zn} . \mathrm{Fe}, \mathrm{Cu}, \mathrm{Mn}$ and $\mathrm{Na}$ in mushrooms and soils were analyzed using an atomic absorption spectrophotometric (AAS). Stock standard solutions of each element were prepared from commercially available mineral standard solution (1000 ppm, Merck, Germany). Each standard solution prepared in different concentrations were adjusted to $50 \mathrm{ml}$ with de-ionized water 
and used for calibrating the AAS (Z-5000 Polarized Zeeman AAS, HITACHI, Japan) system. The mushroom and soil samples were passed through the calibrated AAS system to analyze the concentration of each mineral. All minerals were analyzed in triplicate directly using the AAS system. The detection limit was defined as the concentrations corresponding to three times the standard deviation of ten blanks. Detection limit values of element in mushrooms and soils as milligrams per $100 \mathrm{~g}(\mathrm{mg} / 100 \mathrm{~g})$ in AAS were $0.989 \mathrm{for} \mathrm{Ca}, 0.989$, for $\mathrm{Zn}, 0.998$ for $\mathrm{Cu}, 0.984$ for $\mathrm{Fe}, 0.998$ for $\mathrm{Mg}, 0.993$ for $\mathrm{Mn}, 0.995$ for K, and 0.995, for Na. BFC measures the potential of fungi to absorb and accumulate minerals in the fruiting bodies of mushrooms. It was calculated as the ratio between the mineral concentration in the mushrooms and the mineral concentration of soils (Kuldo et al. 2013).

\section{Results and Discussion}

\section{Morphology and microcharacteristics of M. dolichaula (strain MFLUCC-13-0579)}

Young fruiting bodies were oval (Figs 1C, 1D). The cap of mature fruiting bodies were convex to plano-convex with a small round, light brown low umbo at the disc and ranged from 10$25 \mathrm{~cm}$ in diameter. The cap surface was covered with brownish granular squamules, which became small and sparse toward margin in mature specimens (Figs 1E, F). Lamellae were free to crowded, with short lamellulae and white when young, white to cream colored when mature. The stipe was long and sub-cylindrical, tapering upwards and slightly enlarged at the base (Fig 1E). The annulus was prominent, ascending, simple, whitish, and membranous in mature fruiting bodies (Fig 1F).

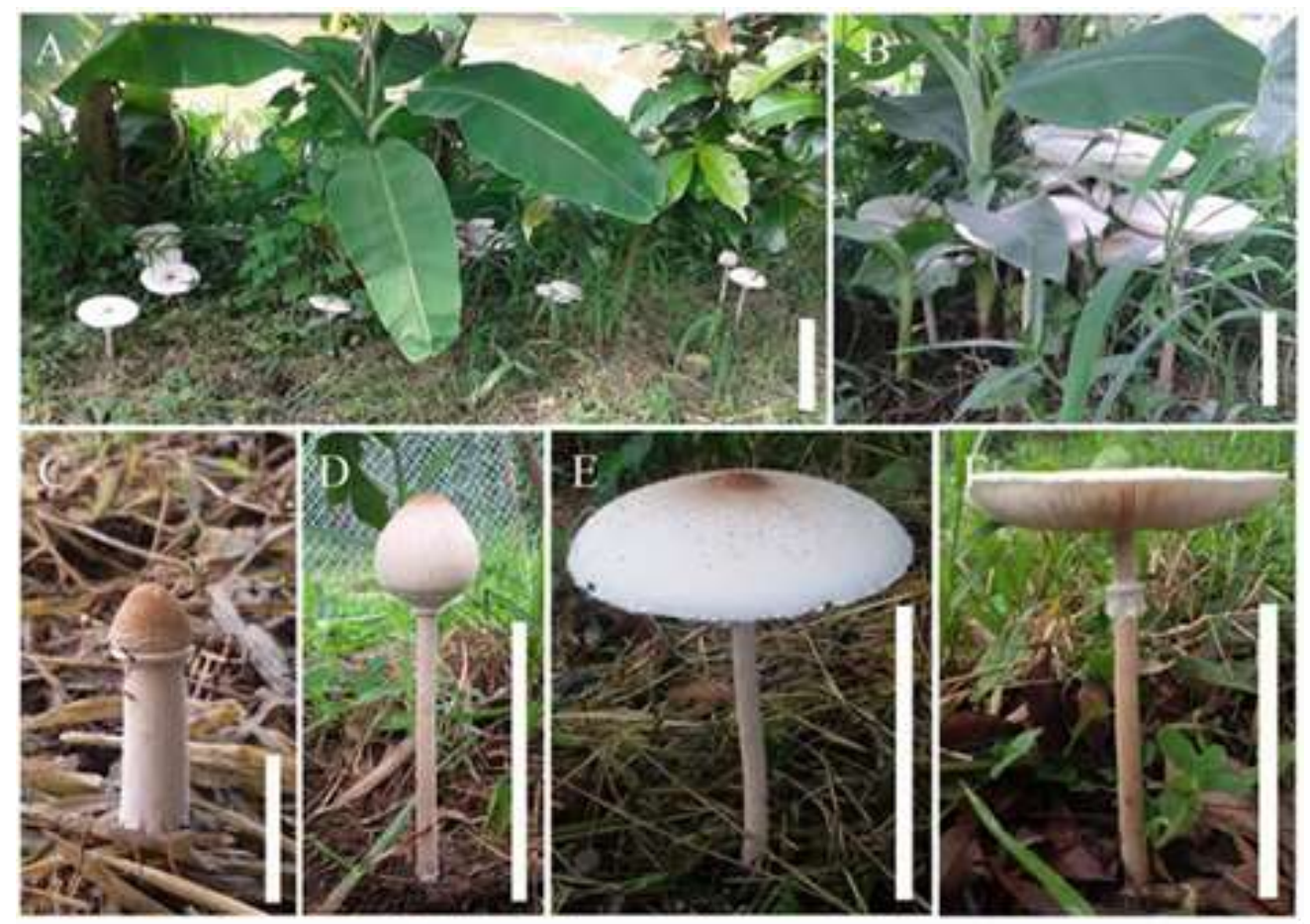

Fig 1-A. Fruiting bodies of $M$. dolichaula under banana plants B. Fruiting bodies growing at single site $\mathrm{C}-\mathrm{F}$. Fruiting bodies at different stages of development under guava trees. Scale bars: $\mathrm{A}=25 \mathrm{~cm} ; \mathrm{B}=10$ $\mathrm{cm}, \mathrm{C}, \mathrm{D}, \mathrm{E}, \mathrm{F}=5 \mathrm{~cm}$.

Basidiospores were covered with hyaline cap. The average size of basidiospores was 10 $13.5 \times 6.5-9 \mu \mathrm{m}$ (Fig 2A). Basidia were 29-34 × 13-17 $\mu \mathrm{m}$ (Fig 2D); and cheilocystidia were hyaline, sub-cylindrical with a rounded apex, 21-34 × 12-16 $\mu \mathrm{m}$ (Fig 2 E). Squamules on the pileus were subcylindric, clampless and 6-15 $\mu \mathrm{m}$ in diameter (Fig. 2 C). Clamp connections were common at the base of basidia and cheilocystidia (Fig 2 B), but rare elsewhere. Morphological features confirmed this as M. dolichaila (Ge et al. 2010). 


\section{Proximate analysis}

The dry weight nutritional content of $M$. dolichaula are shown in Table.1. Macrolepiota dolichaula is good source of protein (27\%), carbohydrates (38\%), fibers (15\%), moisture (8\%) and ash (10\%). This mushroom has low lipid content $(2 \%)$. The relatively low lipid contents, fibers and ash content make this mushroom ideal for consumption for those with cholesterol related ailments (Poddar et al. 2013). Therefore this mushroom can be categorized as a good edible mushroom because of its nutritional values, which are for example, higher than tropical Laetiporus sulphureus which has a long history of consumption especially in North America (Gilbertson \& Ryvarden 1986), Japan (Imazeki et al. 1998), and Thailand (Luangharn et al. 2014).

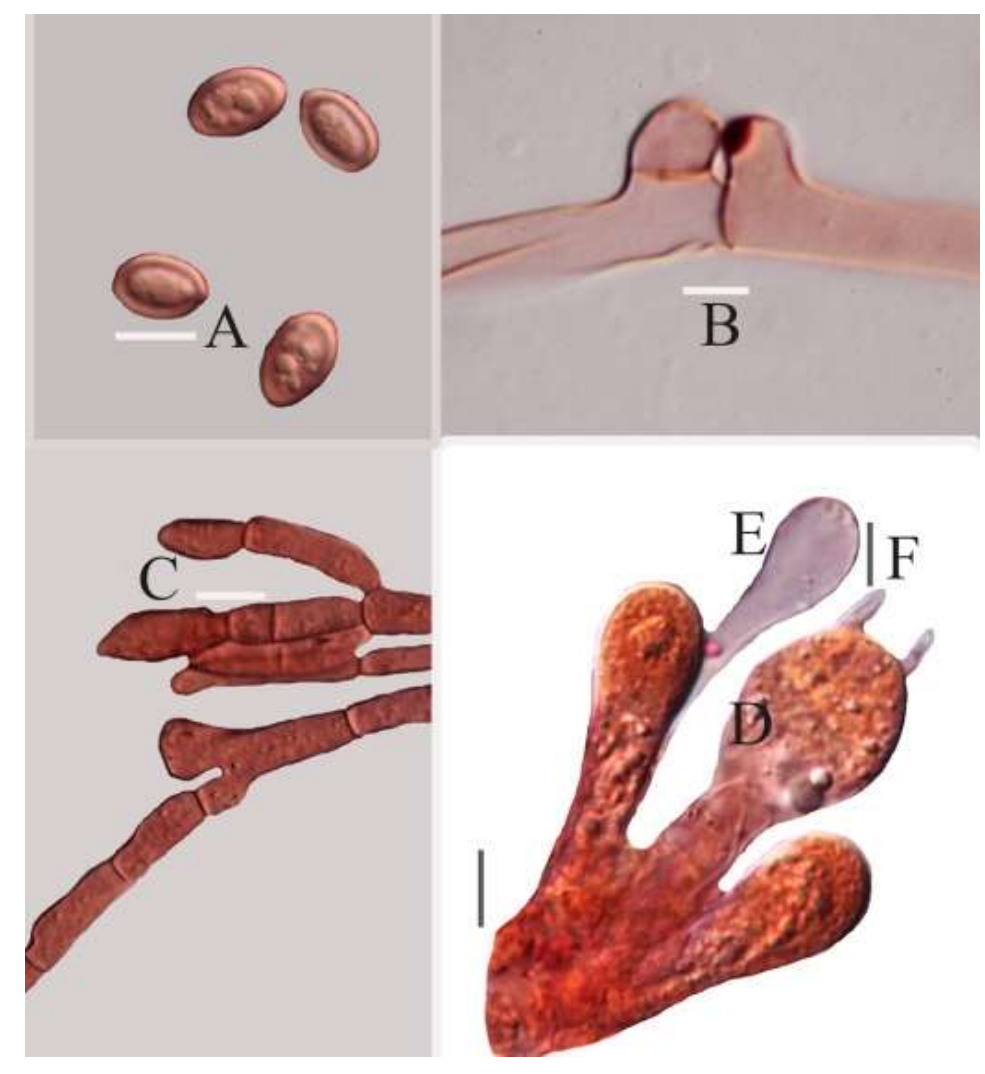

Fig 2 - Microcharacters of M. dolichaula. A. Basidiospore B. Clamp connection at the base of basidia C. Squamules covering pileus D. Basidia E. Cheilocystidia F. Sterigmata Scale bars: A=10 $\mu \mathrm{m}, \mathrm{B}=10 \mu \mathrm{m}, \mathrm{C}=15 \mu \mathrm{m}, \mathrm{D}=10 \mu \mathrm{m}, \mathrm{E}=20 \mu \mathrm{m}$.

Table 1 Nutritional composition (\% dried weight) and energy value (KJ/100g) of M. dolichaula

\begin{tabular}{lc}
\hline Nutritional composition & Amount \\
\hline Ash & $10.19 \pm 0.59$ \\
Fibers & $15.69 \pm 0.42$ \\
Protein & $27.36 \pm 0.08$ \\
Lipids & $01.59 \pm 0.16$ \\
Moisture & $07.60 \pm 0.12$ \\
Carbohydrates & $37.57 \pm 0.08$ \\
Energy & $285.60 \pm 0.07$ \\
\hline
\end{tabular}

Data shown are means and standard deviations of triplicate determinations.

\section{Mineral content in fruiting bodies and adjacent soils}

The data on mineral concentration of $M$. dolichaula and soils, and bio-concentration value are summarized in Table 2. 
Table 2 Total mineral composition $(\mathrm{mg} / 100 \mathrm{~g} \mathrm{dw})$ in $M$. dolichaula fruiting bodies and adjacent soils with bioconcentration values

\begin{tabular}{cccc}
\hline Minerals & Mushroom & Soil & $\begin{array}{c}\text { Bioconcentration } \\
\text { values }\end{array}$ \\
\hline $\mathrm{Ca}$ & $0.34 \pm 0.05$ & $14.58 \pm 0.02$ & $0.02 \pm 0.01$ \\
$\mathrm{Zn}$ & $1.69 \pm 0.42$ & $0.99 \pm 0.01$ & $1.71 \pm 0.00$ \\
$\mathrm{Cu}$ & $1.94 \pm 0.22$ & $0.64 \pm 0.01$ & $3.03 \pm 0.00$ \\
$\mathrm{Fe}$ & $15.94 \pm 6.44$ & $5.77 \pm 0.03$ & $2.77 \pm 0.00$ \\
$\mathrm{Mg}$ & $0.99 \pm 0.97$ & $0.61 \pm 0.00$ & $1.62 \pm 0.00$ \\
$\mathrm{Mn}$ & $0.81 \pm 0.25$ & $2.21 \pm 0.01$ & $0.36 \pm 0.00$ \\
$\mathrm{Na}$ & $5.83 \pm 3.29$ & $2.78 \pm 0.01$ & $2.09 \pm 0.00$ \\
\hline
\end{tabular}

Data shown are the mean from triplicate determinations; dw: dry weight

The mineral content (per $\mathrm{mg} / 100 \mathrm{~g} \mathrm{dw}$ ) in fruiting bodies of $M$. dolichaula and adjacent soils are shown in Table 2 . These data, largely agree with the observations made for a $M$. procera collected from a forest in Poland (Falandysz \& Gucia 2008). Macrolepiota dolichaula can be considered as good dietary source of essential minerals, such as $\mathrm{Fe}, \mathrm{Na}, \mathrm{Cu}, \mathrm{Zn}$ and $\mathrm{Mg}$, which play important roles in metabolic reactions, conduction of nerve impulses, rigid bone formation and regulation of water and salt balances (Kumari \& Atri 2014). The high content of iron in soils $\mathrm{pH}$ 6.8 is close to pork liver, which has about 12 times iron content as compared to most vegetables (Tomovic et al. 2011, Yi et al. 2014). This mushroom may therefore supplement iron in diets.

The bioconcentration factor provides an idea of a mushroom species potential for up-take of mineral (Genccelep et al. 2009). Macrolepiota dolichaula is efficient in accumulating $\mathrm{Fe}, \mathrm{Na}, \mathrm{Zn}$, $\mathrm{Cu}$ and $\mathrm{Mg}$ which are poor in sample soils (median $\mathrm{BCF}>1$ ). $\mathrm{Ca}$ and $\mathrm{Mn}$ were however, poorly accumulated even though concentrations in soils were higher than in the fruiting bodies. The data are shown in Table 2.

The $\mathrm{Cu}, \mathrm{Fe}, \mathrm{Na}$ and $\mathrm{Mg}$ content in the fruiting bodies are within the acceptable range for human consumption (Kumari \& Atri 2014). Alonso et al. (2003) found that Macrolepiota procera and Agaricus bisporus have lower bioconcentration values for $\mathrm{Zn}$ as compared to the mycorrhizal mushrooms such as Boletus edulis, Lactarius deliciosus, and Leccinum scabrum. These variations in $\mathrm{Zn}$ results from various abiotic factors such as the characteristics of the soils, $\mathrm{pH}$, minerals and external depositions or addition of metals on soils where the mushroom grows (Aruguete et al. 1998, Alonso et al. 2003, Colak et al. 2009). This study showed that M. dolichaula can accumulate minerals important for human biological systems.

\section{Conclusion}

Our study showed the proximate and mineral content of $M$. dolichaula. This mushroom is edible, cultivable and thus these data are important and can be used to indicate its nutritive quality. Because of the high accumulating potential of this mushroom for $\mathrm{Fe}, \mathrm{Na}, \mathrm{Cu}, \mathrm{Zn}$ and $\mathrm{Mg}$, fruiting bodies of $M$. dolichaula are rich in minerals and thus good for consumption by animals and humans.

\section{Acknowledgements}

The author kindly acknowledges Mae Fah Luang University, Thailand for the Royal Wedding Scholarship, 2013 and Mae Fah Luang University project 'Taxonomy, phylogeny and cultivation of Lentinus species in northern Thailand' [grant number MFU-54101020048]. The study would not have been possible without generous support from Ministry of Education and Royal Civil Service Commission, Bhutan. The Thailand Research Fund grant - Taxonomy, Phylogeny and biochemistry of Thai Basidiomycetes (BRG 5580009) are also thanked for support. 


\section{References}

Alonso J, Garcia MA, Perez-lopez M, Melger MJ. 2003 - The concentrations and bioconcentration factors of copper and zinc in edible mushrooms. Archives Environmental Contamination and Toxicology 44, 180-188.

AOAC. 1995 - Association of Official Analysis Chemistry Official Methods of Analysis of AOAC international. Washington, DC.

Aruguete DM, Joseph L, Aldstadt JH, Mueller GM. 1998 - Accumulation of several heavy metals and lanthanides in mushrooms Agaricales from the Chicago region. Science of Total Environment 224, 43-56.

Baptista P, Ferreira S, Soares E, Coelho V, De Lourdes Bartos M. 2009 - Tolerance and stress response of Macrolepiota procera to nickel. Journal of Agriculture and Food Chemistry 57, 7145-7152.

Colak A, Kolcuoolu Y, Sesli E, Dalman O. 2007 - Biochemical composition of some Turkish fungi. Asian Journal of Chemistry 19, 2193-2199.

Colak A, Faiz O, Sesli E. 2009 - Nutritional composition of some wild edible mushroom, Turkey Journal Biochemistry 34, 25-1.

Falandysz J, Gucia M. 2008 - Bioconcentration factors of mercury by Parasol mushroom (Macrolepiota procera). Environmental Geochemical Health 30, 121-125.

Falandysz J, Kunito T, Kubota R, Gucia M, Mazur A, Falandysz JJ, Tanabe S. 2008b - Some mineral constituents of Parasol Mushroom (Macrolepiota procera). Journal of Environmental Science Health, 43, 187-192.

Fujihara S, Kasuga A, Aoyagi Y, Sugahara T. 1995 - Nitrogen-to-protein conversion factors for some common edible mushrooms. Journal of Food Science 60, 1045-1047.

Ge Z.W, Yang ZL, Vellinga EC. 2010 - The genus Macrolepiota (Agaricaceae, Basidiomycota) in China. Fungal Diversity 45, 81-98.

Genccelep H, Uzun Y, Tuncturk Y, Demirel K. 2009 - Determination of mineral contents of wildgrown edible mushrooms. Food Chemistry 113, 1033-1036.

Gilbertson RL, Ryvarden L.1986 - North American Polypores. Fungiflora, Oslo, Norway.

Imazeki R, Otani Y, Hongo T. 1998 - Fungi in Japan (in Japanese), Tokyo, Yama-kei.

Kuldo E, Jarzynska G, Gucia M, Falandysz J. 2013 - Mineral constituents of edible Parasol mushroom Macrolepiota procera (Scop. Ex Fr.) Sing and soils beneath its fruiting bodies collected from a rural forest area. Chemical papers 64, 484-492.

Kumari B, Atri AS. 2014 - Nutritional and nutraceutical potential of wild edible macrolepiotoid mushrooms of north India. International Journal of Pharmacy \& Pharmaceutical 6, 200-204.

Kumari B, Artri NS, Upadhyay RC. 2012 - Screening and evaluation of extra-cellular oxidases in some Termitophilous and Lepiotoid mushrooms. World Journal of Agricultural Sciences 8, 409-414.

Luangharn T, Hyde KD, Chukeatirote E. 2014 - Proximate analysis and mineral content of Laetiporus sulphureus strain MFLUCC 12-0546 from northern Thailand. Chiang Mai Journal of Science 41, 1-6.

Poddar KH, Ames M, Hsin-Jen C, Feeney MJ, Wang Y, Cheskin LJ. 2013 - Positive effect of mushrooms substituted for meat on body weight, body composition and health parameters. A 1-year randomized clinical trial. Appetite 71, 379-387.

Samanta S, Nandi AK, Sen IK, Maji PK, Devi KSP, Maiti TK, Islam SS. 2013 - Structural characterization of an immunoenhancing glucan isolated from a mushroom Macrolepiota dolichaula. International Journal Biological Macromolecules 61, 89-96.

Tomovic VM, Petrovic LS, Tomovic MS, Kevresan ZS, Dzinic NR. 2011 - Determination of mineral contents of semimembranosus muscle and liver from pure and crossbred pigs in Vojvodina (northern Serbia). Food Chemistry 1, 342-348.

Vetter J, Siller I. 1997 - Asvanyi anyagok mennyisegenek alakulasa a gomba ter otestben (Macrolepiota procera). Mikologiai KozlemEnyek 36, 33-38. 
Yi L, Zhang J, Yajuan X, Wang Y, Lu Y, Liu Y. 2014 - The analysis for the nutritional ingredient of wild edible fungus in tourist attraction-taking Yunnan Province as an example. Advance Journal of Food Science Technology 11, 1272-1276. 